\title{
A Qualitative System Dynamic Modelling on Sustainable Tourism Development (Case Study: Depok Beach at Bantul Regency)
}

\author{
Didi Nuryadin ${ }^{1}$, Jamzani Sodik1, Wahyu Dwi Artaningtyas ${ }^{1}$ \\ ${ }^{1}$ Faculty of Economic and Business, UPN Veteran Yogyakarta, Indonesia
}

\begin{abstract}
Depok beach is a tourism destination located in Yogyakarta's south coastal area with its unique attractions. The tourism development at Depok beach finds some problems, especially on tourism sustainability. This research tried to model a system for managing Depok beach as a sustainable tourist attraction. System dynamics were used for modeling the management strategy. The data of this study were gathered by doing observation and in-depth interviews with related stakeholders. This research found that the Depok beach management model is a complex system consisting of social, economic, and ecological subsystems. The management system of Depok beach was quite nice, even one environmental aspect, which is waste management was not fully appropriate. Locals waste management was done traditionally, neglecting any ecological problems that may be occurred. The optimization of Depok beach management might be achieved by strengthening the waste management system.
\end{abstract}

Keywords: marine tourism, sustainable tourism management, system dynamics, system thinking

\section{INTRODUCTION}

The Yogyakarta south coast area is the most attractive destination in the DIY province. According to government regulation of the Republic of Indonesia number 50 of 2011 concerning the master plan of national tourism development in 2010-2055, Depok beach categorizes as a strategic national tourism area. Before the legalization of that government regulation, Depok beach was a fishermen's village (Nawawi, 2015)with unique attractions and blessed with marine wealth (Setyaningrum et al., 2018), which became the primary income for local communities. Therefore, tourism development at Depok beach must be undertaken to raise locals' prosperity through employment (Brouder, 2012).

The strategy to develop Depok beach should consist of complex things, such as connecting economic growth activities, tourism areas, and local engagement (Pafi et al., 2020). The strategy also should reflect marine sustainability (Wei et al., 2013), mainly on waste management issues that have not been controlled yet (Rudianto dan Ciptono, 2018), the decline of local's participation, and the lack of tourism management itself (Nawawi, 2015; Setyaningrum et al., 2018). The marine sustainability issue, indepth, should be focused more on because of its excessive use in the past decade (Wei). Therefore, the strategy must have a capacity to balance all sustainability aspects and been determined precisely to avoid any risks (Priatmoko, 2018) and negative externalities (Zanker dan Štekerová, 2020).

There are many approaches to choose a strategy to develop Depok beach as a tourism destination. One of them is system dynamics modeling. System dynamics help the researcher understanding a complex system, understanding the origin of regulation and its development process (Sterman, 2002), and 
estimating the effects of a regulation (Firmansyah dan Pramudya, 2016). This approach is promoted in the tourism industry to reach a holistic understanding of complex problems and as a foundation for developing new effective regulations (Sedarati et al., 2019). Based on the discussion, the objective of this study is to make a sustainable model of Depok beach management as a tourism destination.

\section{LITERATURE REVIEW}

\section{Sustainable Tourism}

Sustainable tourism as a theory has two fundamental elements, development and sustainability, consisting of ecological, social, and economic sustainability (Klarin, 2018). According to World Tourism Organization (2005), sustainable tourism meets the needs of present tourists and host regions while protecting and enhancing opportunities for the future. Enhancing opportunities are the key element in the tourism element (Kawatak et al., 2020). Sustainable tourism as a comprehensive concept must be measured by four indicators: socio-cultural, economic, environmental, and institutional sustainability (Asmelash dan Kumar, 2019).

Nowadays, sustainable tourism focuses more on preserving cultural heritages and natural life, which is far from exposing non-physical aspects like supportive cultural and environmental. Although, tourists are more likely to expect to have extraordinary experience and profound understanding about specific destinations through best service (Amerta et al., 2015).

\section{The Development of Marine Tourism}

Any National tourism development should honor local identity, especially culture, natural resources, norms, and religion (Tegar dan Saut Gurning, 2018). Government regulation of the Republic of Indonesia, number 50 of 2011 concerning the master plan of national tourism development in 2010-2055, shepherds National tourism development to optimize natural resources on three categories: marine tourism, eco-tourism, and adventure tourism. Marine tourism makes use of natural attractions with its diverse and unique marine ecosystem. Marine tourism could be specified into three:

1. Coastal zone for sun-bathing, sightseeing, beach sport, and attractive show

2. Sea zone for sailing, yachting, and cruising

3. Underwater zone for diving (Sugihamretha)

Tourism development, according to Sulistiyono, starts with analyzing four factors: man, machine, media, and management. Moreover, tourism development should be able to synergize citizen, natural resources, geographical conditions such as climate and weather, and marine ministry by considering some fundamental aspects (Tegar dan Saut Gurning, 2018):

1. Safe, comfortable, attractive, easy access, and eco-friendly destination.

2. Increasing tourist and host region visitation rate by doing synergic, advanced, and trustworthy marketing.

3. Creating a competitive and credible tourism industry by respecting nature and socio-cultural.

4. The regional and central government, public and private organization, human resource, regulation, and effective-efficient operational mechanism to grow sustainable tourism development.

\section{System Dynamics Modeling}

Jay W. Forrester developed system dynamics first to find a solution to any social problems (Prahasta, 2018). System dynamics is used to understand a complex system, to understand the origin of 
regulation, then develop a policy (Sterman, 2002), to analyze policy effect (Arquitt dan Johnstone, 2008), and to understand any factor effect towards organizational/systemic goal (Guan et al., 2011; Yao et al., 2011). System dynamics systematically has three main elements: looping feedback, variable, and equity (Vafa-Arani et al., 2014).

System dynamics is identified by non-linear connection causing back-forth relationship, depends on the system condition (Forrester, 2007). This connection changes the dominance relation, which is crucial in determining behavioral intention. Some frequent tools used to create a system dynamics structure are Causal Loop Diagram (CLD) and Stock and Flow Diagram (SFD). CLD and SFD, in general, interpret a red-line of a dynamic system. Those diagrams are one of the uniqueness of system dynamics compared to system thinking (Prahasta, 2018). CLD and SFD usually be written in a scheme by using symbols with different definitions (Vafa-Arani et al., 2014).

\section{RESEARCH METHOD}

This research used system dynamics as a model to develop a sustainable model of Depok beach management as a tourism destination. In-depth review and observation were chosen as data collection techniques and held on Mei until June 2021. In analyzing data, the researcher utilized Vensim PLE software.

System dynamics in this research were developed based on Depok beach's actual condition and constructed with the researcher's mental model, respondents of this research, and some earlier research. Those specific factors favorably made quite different research result compared to similar research in other places. Therefore, the system dynamics modeling on this research relied on the researcher and respondent's capacity to create a model similar to the existing system. System dynamics is suitable for understanding complex problems such as sustainable tourism development (Schwarz et al., 2010). There were four system dynamics phases: observing, creating a conceptual model, interpreting, and using the developed model (Rusiawan et al., 2015).

\section{FINDINGS AND DISCUSSION}

The development of Depok beach as a tourist attraction (ODTW) meets many problems, especially its sustainability. Sustainability is important because of the excessive use of natural resources (Wei et al., 2013). The dependency among social system, economy, environment, and their effects throughout tourism sustainability also should be considered (Burger et al., 2012). Those aspects make the development strategy of Depok beach as a tourist attraction becomes complex.

The preliminary model of Depok beach management presents in a causal loop diagram. Picture 1 shows the model of Depok beach tourism management, which consists of social, economic, and environmental aspects. 


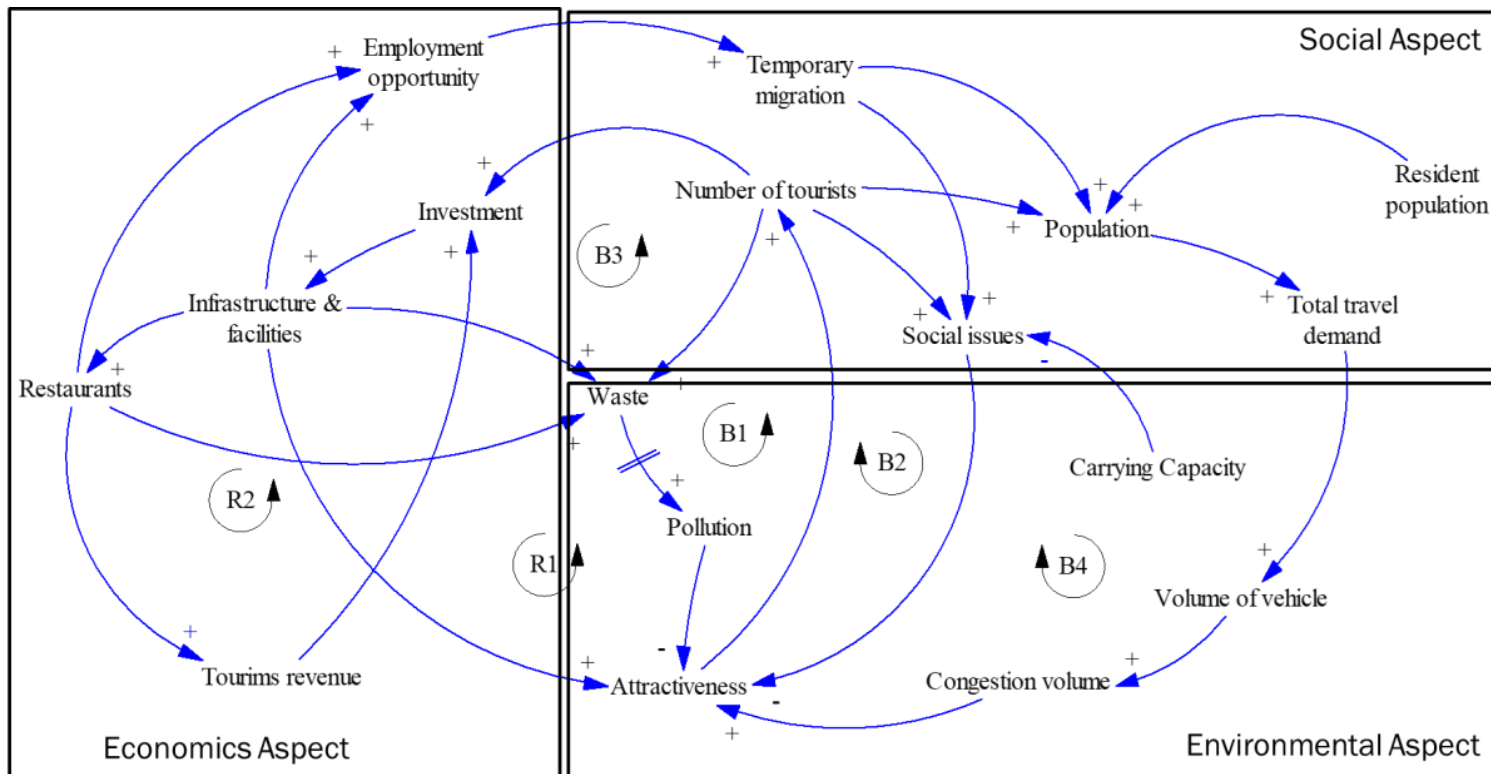

Figure 1. Causal Loop Diagram of Depok Beach Development

\section{Social Aspect}

Social sustainability is popular with preserving cultural and local identity, tributing cultural, race, and religious diversity, preserving social values and norms, preserving equity and human right (Klarin, 2018). Some research proved an improvement of local's quality of life phenomenon since Depok beach has been becoming a tourist attraction. The development of the coastal zone will affect local's social aspects such as nutrition quality improvement because of consuming seafood, health quality improvement because of the growth of healthcare availability, and educational quality improvement because of the growth of local's participation rate in education (Alencar et al., 2020).

In contrast, the development of Depok beach as a tourist attraction may create new social problems, the emergence of slums. Since Depok beach has become economic growth, people from other areas would gather and make their shelters to cut transportation costs. This concentration of new shelters could potentially harm the marine environment because of the lack of waste management. Coastal development as a tourism attraction would create social problems caused by social discrepancy and economic and health problems (Alencar et al., 2020).

\section{Economics Aspect}

The results of the research show that Depok Beach is able to have a positive impact on the economy, such as opening up business opportunities and job opportunities for the surrounding community. This increase will certainly reduce the percentage of poverty around the coast (Alencar et al., 2020). In general, the people around the Depok coast work as fish traders or processed fish, fishermen, there are even residents who sell their creativity such as making decorations at several points as photo spots, kite craft traders to APV car rental. This is supported by the statement of Rudianto dan Ciptono (2018), which explains that the Depok beach has so far been able to provide a good economic impact on the community through increased tourist activity in attendance.

Revenue at Depok Beach can be used to improve infrastructure such as waste management because inadequate waste management will disturb the comfort of tourists. What's more, the potential increase 
will occur as the number of visiting tourists increases. This is in line with the research results of Alencar et al. (2020), which explains that coastal tourism revenues can be used to improve and even improve infrastructure in tourist areas and their surroundings. Improvements and improvements to the infrastructure are expected to make visitors more comfortable and safer so that the desire to visit again arises. In the future, this will certainly have a positive impact on the sustainability of tourism in Depok Beach.

Another problem that needs to be considered is the dependence of the surrounding community on existing natural resources. Moreover, the main work of the surrounding community is highly dependent on natural resources in Depok Beach and is supported by uncertainty regarding the availability of these resources. This will certainly have an impact on the sustainability of the community's business which is also one of the leading attractions on Depok Beach. The utilization and regulation of marine resources should be carried out carefully to avoid damage to populations, habitats, and ecosystems (Darmawan dan Harimas Ginting, 2020). Therefore, awareness is needed from various parties to preserve marine resources considering its enormous potential for economic improvement.

\section{Environmental Aspect}

Ecological sustainability is a continuous effort in preserving environmental quality for economic activity and quality of life. Some practices of this effort include protecting nature, decreasing emission and pollution, controlling the use of the resource, etc. (Klarin, 2018). Waste management in Depok beach, according to researchers, is not appropriate yet. Locals manage their waste by throwing it off into outfall or burning it on outfall, potentially harming surrounding water and air, inconveniencing tourists and host regions. Fishers, marine debris and local communities are the suppliers of Depok beach waste. Thus, the increasing rate of tourist visitation also contributes to Depok beach waste. Depok beach waste management is still not on good terms, which ignoring coastal neatness and not associating locals to maintain coastal neatness, and may interfere with the development of Depok beach as a tourist attraction (Nawawi, 2015; Rudianto dan Ciptono, 2018; Setyaningrum et al., 2018).

The management of Depok beach as a sustainable tourist attraction theoretically makes the waste management system fully efficient that positively increases water and air quality and neats the coastal area. The appropriate management may raise the visitation rate, which affects locals' economic (Raworth, 2017). In fact, the waste infrastructure cannot accommodate a large amount of trash, especially on peak tourism days (Ghosh, 2012). The high tourist concentration triggers higher use of transportation modes which causing uncontrolled air pollution. Consequently, the need for waste awareness shown by locals, tourists, and management is a must to reach a sustainable tourist attraction.

\section{CONCLUSION}

Depok beach is a tourist attraction located on the strategic national tourism area, at south Yogyakarta coastal area. It has a unique identity compared to others, such as the beauty of coastal views and a variative seafood culinary. Besides its attractiveness, Depok beach still lacks waste management, whereas locals usually burn trash in outfalls which is not good for the environment. Because of that, the sustainability of tourist attractions, especially environmental sustainability, is critical in managing Depok beach. Sustainability on tourist attractions in general consists of social, economic, and environmental aspects. The increasing visitors' rate at Depok beach potentially harms the environment if not being controlled well. In sum, the sustainable tourism development at Depok beach might be achieved if locals and tourists are aware of succeeding in this development. 
RSF Conference Series: Business, Management and Social Sciences, Vol. 1 (3), 40-46

A Qualitative System Dynamic Modelling on Sustainable Tourism Development (Case Study: Depok Beach at

Bantul Regency)

Didi Nuryadin, Jamzani Sodik, Wahyu Dwi Artaningtyas

\section{REFERENCES}

Alencar, N.M.P. de, Le Tissier, M., Paterson, S.K., Newton, A., 2020. Circles of coastal sustainability: A framework for coastal management. Sustain. 12, 1-27.

Amerta, I.M.S., Sara, I.M., Bagiada, K., 2015. Sustainable tourism development. Routledge Int. Handb. Sustain. Dev. 5, 250-263.

Arquitt, S., Johnstone, R., 2008. Use of system dynamics modelling in design of an environmental restoration banking institution. Ecol. Econ. 65, 63-75.

Asmelash, A.G., Kumar, S., 2019. Assessing progress of tourism sustainability: Developing and validating sustainability indicators. Tour. Manag. 71, 67-83.

Brouder, P., 2012. Creative Outposts: Tourism's Place in Rural Innovation. Tour. Plan. Dev. 9, 383396.

Burger, J.R., Allen, C.D., Brown, J.H., Burnside, W.R., Davidson, A.D., Fristoe, T.S., Hamilton, M.J., Mercado-Silva, N., Nekola, J.C., Okie, J.G., Zuo, W., 2012. The macroecology of sustainability. PLoS Biol. 10.

Darmawan, E., Harimas Ginting, A., 2020. Tata Kelola Kebijakan Maritim di Indonesia dalam Perspektif Sound Governance. Transform. J. Manaj. Pemerintah. 12, 36-50.

Firmansyah, I., Pramudya, B., 2016. Sustainability status of rice fields in the rice production center of Citarum Watershed 8, 13-26.

Forrester, J.W., 2007. System dynamics - a personal view of the first fifty years $† 23,345-358$.

Ghosh, T., 2012. Sustainable Coastal Tourism: Problems and Management Options. J. Geogr. Geol. 4.

Guan, D., Gao, W., Su, W., Li, H., Hokao, K., 2011. Modeling and dynamic assessment of urban economy - resource - environment system with a coupled system dynamics - geographic information system model. Ecol. Indic. 11, 1333-1344.

Kawatak, S.Y., Indriyanto, M.N., Jangkobus, Y.M.K.H., 2020. Government's role in developing sustainable tourism at Sangihe Island Regency. J. Ilm. Hosp. 9, 77-86.

Klarin, T., 2018. The Concept of Sustainable Development: From its Beginning to the Contemporary Issues. Zagreb Int. Rev. Econ. Bus. 21, 67-94.

Nawawi, A., 2015. Partisipasi Masyarakat Dalam Pengelolaan Wisata Pantai Depok Di Desa Kretek Parangtritis. J. Nas. Pariwisata 5, 103-109.

Pafi, M., Flannery, W., Murtagh, B., 2020. Coastal tourism , market segmentation and contested landscapes. Mar. Policy 121, 104189.

Prahasta, E., 2018. System Thinking dan Pemodelan Sistem Dinamis. Informatika, Bandung.

Priatmoko, S., 2018. Analysis of Marketability, Sustainability, Participatory and Disaster Mitigation (MSP+DM) for the development of rural Community-Based Tourism (CBT) destinations Case study: Depok beach, Bantul, Yogyakarta. IOP Conf. Ser. Earth Environ. Sci. 202.

Raworth, K., 2017. A Doughnut for the Anthropocene: humanity's compass in the 21st century. Lancet Planet. Heal. 1, e48-e49.

Rudianto, R.A., Ciptono, W.S., 2018. Valuasi Pantai Depok Kabupaten Bantul pada tahun 2017. Universitas Gadjah Mada.

Rusiawan, W., Tjiptoherijanto, P., Suganda, E., Darmajanti, L., 2015. System Dynamics Modeling for Urban Economic Growth and CO2 Emission: A Case Study of Jakarta, Indonesia. Procedia Environ. Sci. 28, 330-340.

Schwarz, N., Haase, D., Seppelt, R., 2010. Omnipresent sprawl? A review of urban simulation models with respect to urban shrinkage. Environ. Plan. B Plan. Des. 37, 265-283. 
Sedarati, P., Santos, S., Pintassilgo, P., 2019. System Dynamics in Tourism Planning and Development. Tour. Plan. Dev. 16, 256-280.

Setyaningrum, A., Setyorini, H.B., Masduqi, E., 2018. Strategi pengembangan pariwisata berbasis sumber daya alam pesisir dan laut di Pantai Depok Daerah Istimewa Yogyakarta. J. Kebijak. Sos. Ekon. Kelaut. dan Perikan. 7, 179.

Sterman, J.D., 2002. Business Dynamics, System Thinking and Modeling for a Complex World, ESDWP-2003-01.13. Cambridge.

Tegar, D., Saut Gurning, R.O., 2018. Development of Marine and Coastal Tourism Based on Blue Economy. Int. J. Mar. Eng. Innov. Res. 2.

Vafa-Arani, H., Jahani, S., Dashti, H., Heydari, J., Moazen, S., 2014. A system dynamics modeling for urban air pollution: A case study of Tehran, Iran. Transp. Res. Part D Transp. Environ. 31, 21-36.

Wei, W., Alvarez, I., Martin, S., 2013. Sustainability analysis: Viability concepts to consider transient and asymptotical dynamics in socio-ecological tourism-based systems. Ecol. Modell. 251, 103-113.

Yao, H., Shen, L., Tan, Y., Hao, J., 2011. Simulating the impacts of policy scenarios on the sustainability performance of infrastructure projects. Autom. Constr. 20, 1060-1069.

Zanker, M., Štekerová, K., 2020. A Decade of System Dynamics Modelling for Tourism: Systematic Review. In: Maresova, P., Jedlicka, P., Firlej, K., Soukal, I. (Ed.), Proceedings of the international scientific conference Hradec Economic Days 2020. hal. 881-893. 